Buletin Ilmiah Mat. Stat. dan Terapannya (Bimaster)

Volume 09, No. 2 (2020), hal $253-260$.

\title{
PENERAPAN MODEL NEURO-GARCH PADA PERAMALAN DATA RETURN SAHAM
}

\author{
Nova Andaresta, Shantika Martha, Dwi Marisa Midyanti
}

\begin{abstract}
INTISARI
Heteroskedastisitas merupakan masalah yang sering terjadi dalam proses peramalan pada data keuangan. Model generalized autoregressive conditional heteroscedasticity (GARCH) merupakan model runtun waktu yang dapat digunakan untuk data yang mengalami heteroskedastisitas. Model lain yang dapat digunakan untuk memodelkan data dengan fluktuasi yang sangat besar dan tidak tetap adalah jaringan saraf tiruan (JST). Dalam penelitian ini kedua model digabungkan menjadi sebuah model yang disebut Neuro-GARCH. Tujuan penelitian ini membentuk arsitektur jaringan model terbaik dan membandingkan hasil peramalan dengan data aktual return saham pada tanggal 11 Juli 2018 sampai dengan 28 Februari 2019. Data yang digunakan adalah data return saham PT Bank Central Asia Tbk penutupan harian pada periode Januari 2017 sampai dengan Februari 2019. Adapun langkah-langkah dalam penelitian ini diawali dengan pembentukan model box jenkins. Residual model box jenkins terbaik digunakan untuk mendeteksi heteroskedastisitas menggunakan uji lagrange multiplier (ARCH-LM). Data residual yang memiliki heteroskedastisitas dimodelkan ke dalam model GARCH. Variabel bebas pada model GARCH kemudian dijadikan input pada model JST dan targetnya adalah data return (aktual). Hasil analisis menunjukkan bahwa bentuk jaringan terbaik adalah (2-5-1) dengan nilai MSE pengujian sebesar 0,00014955. Hasil peramalan selama 167 hari mengalami fluktuasi, dengan return tertinggi yaitu pada tanggal 14 September 2018 sebesar 0,0128467 dan terendah terjadi pada tanggal 13 Juli 2018 sebesar $-0,0049574$.
\end{abstract}

Kata Kunci: ARIMA, heteroskedastisitas, JST, backpropagation

\section{PENDAHULUAN}

Peramalan (forecasting) merupakan alat bantu yang sangat penting dalam perencanaan yang efektif dan efisien, khususnya dalam bidang ekonomi dan organisasi bisnis dalam setiap pengambilan keputusan yang sangat signifikan. Peramalan menjadi dasar bagi perencanaan jangka pendek maupun jangka panjang bagi perusahaan [1]. Masalah yang sering terjadi dalam proses peramalan pada data keuangan adalah heteroskedastisitas. Heteroskedastisitas merupakan keadaan variansi residual bersifat tidak sama (konstan). Data yang mengandung heteroskedastisitas akan mempunyai variansi yang tinggi sehingga hasil peramalan menjadi tidak efisien [2].

Model runtun waktu yang dapat digunakan untuk data yang mengalami heteroskedastisitas adalah model autoregressive conditional heteroscedasticity (ARCH) yang pertama kali diperkenalkan oleh Engle pada tahun 1982. Pada tahun 1986, Bollerslev memperkenalkan pengembangan dari model ARCH yakni model generalized autoregressive conditional heteroscedasticity (GARCH). Model GARCH dapat digunakan untuk menggambarkan sifat dinamik fungsi volatilitas (standar deviasi) dari data [3].

Model lain yang dapat digunakan untuk memodelkan data dengan fluktuasi yang sangat besar dan tidak tetap adalah jaringan saraf tiruan (JST). JST merupakan sistem pemroses informasi yang meniru sistem jaringan saraf biologi. Salah satu algoritma pelatihan dari JST adalah backpropagation. Backpropagation menggunakan arsitektur multilayer dengan metode pembelajaran terawasi. Salah satu bidang dimana backpropagation dapat diaplikasikan dengan baik adalah dalam bidang peramalan (forecasting) [4]. Gabungan antara model GARCH dan JST disebut dengan model Neuro-GARCH. Pada model Neuro-GARCH, input yang digunakan adalah variabel bebas dari model GARCH yang terbentuk dan targetnya merupakan data return (aktual). 
Tujuan penelitian ini adalah untuk membentuk arsitektur jaringan model terbaik dalam meramalkan return saham dan membandingkan hasil peramalan dengan data aktual return saham PT Bank Central Asia Tbk pada tanggal 11 Juli 2018 sampai dengan 28 Februari 2019 menggunakan model Neuro-GARCH. Data yang digunakan adalah data return saham PT Bank Central Asia Tbk penutupan harian sebanyak 558 data dari bulan Januari 2017 sampai dengan Februari 2019. Langkah awal yang dilakukan yaitu menghitung return dari data saham. Setelah data return saham terbentuk, dilakukan uji stasioneritas data dengan menggunakan uji augmented dickey fuller (ADF). Apabila data tidak stasioner maka dilakukan differencing atau transformasi agar data menjadi stasioner. Selanjutnya menentukan model awal yang sesuai menggunakan model box jenkins. Setelah didapatkan model sementara yang teridentifikasi, langkah berikutnya adalah mengestimasi parameter model box jenkins serta menguji signifikansi parameternya. Kemudian dilakukan verifikasi model meliputi uji independensi residual. Langkah berikutnya adalah pemilihan model terbaik, kemudian diuji residualnya menggunakan uji lagrange multiplier (ARCH-LM) untuk melihat adanya efek ARCH/GARCH. Jika terdapat efek ARCH/GARCH maka return saham dibentuk ke dalam model GARCH. Berdasarkan model GARCH terbaik kemudian dibentuk input dan target. Dilakukan inisialisasi jaringan dengan menentukan arsitektur jaringan. Setelah itu pembagian komposisi data pelatihan dan data pengujian. Selanjutnya dilakukan proses pelatihan dan pengujian. Langkah terakhir adalah pemilihan model Neuro-GARCH terbaik berdasarkan nilai MSE pengujian terkecil.

\section{RETURN SAHAM}

Return saham adalah hasil yang diperoleh investor terhadap investasi saham yang dilakukan sehingga dapat memberikan keuntungan atau kerugian. Risiko dalam berinvestasi erat kaitannya dengan return, karena investor mengharapkan return yang sesuai dengan risiko yang dihadapi. Return saham dibedakan menjadi dua yaitu return realisasi adalah return yang terjadi (return sesungguhnya) dan return ekspektasi adalah return yang diharapkan oleh investor di masa mendatang. Return saham dapat rumuskan sebagai berikut [5]:

$$
r_{t}=\ln \left(\frac{P_{t}}{P_{t-1}}\right)
$$

dengan $r_{t}$ adalah return saham, $P_{t}$ adalah harga saham pada waktu ke-t dan $P_{t-1}$ harga saham pada waktu t-1.

\section{AKAIKE INFORMATION CRITERION (AIC)}

Akaike information criterion (AIC) merupakan pengukuran untuk kualitas relatif dari model statistik dari data yang diberikan untuk pemilihan model terbaik dari beberapa model yang ada. Untuk menghitung nilai AIC digunakan rumus seperti berikut [6]:

$$
A I C=-2\left(\frac{l}{n}\right)+2\left(\frac{k}{n}\right)
$$

dengan $l=-\frac{n m}{2}(1+\log 2 \pi)-\frac{n}{2} \log |\widehat{\Omega}| \operatorname{dimana}|\widehat{\Omega}|=\operatorname{det}\left(\sum^{\hat{\varepsilon} \hat{\varepsilon}^{\prime}} / n\right), m$ adalah jumlah persamaan, $k$ adalah jumlah parameter yang diestimasi dalam model regresi, $n$ adalah banyaknya data pengamatan.

\section{LAGRANGE MULTIPLIER (ARCH-LM)}

Uji ARCH-LM digunakan untuk mengetahui ada atau tidaknya efek heteroskedastisitas pada data runtun waktu [3]. Hipotesis awal $\left(\mathrm{H}_{0}\right)$ adalah tidak terdapat heteroskedastisitas. $\mathrm{H}_{0}$ ditolak jika nilai $F>F_{\text {tabel }}$ atau nilai prob $<\alpha$ [7]. Dengan statistik uji $\mathrm{F}$ adalah [8]:

$$
F=\frac{\left(S S R_{0}-S S R_{1}\right) / p}{S S R_{1} /(n-2 p-1)}
$$

dimana $S S R_{0}=\sum_{t=p+1}^{n}\left(\varepsilon_{t}^{2}-\bar{\varepsilon}\right)^{2}, \varepsilon_{t}$ adalah proses white noise, $S S R_{1}=\sum_{t=p+1}^{n} \hat{e}_{t}^{2}, \hat{e}_{t}$ adalah residual kuadrat terkecil, $\bar{\varepsilon}$ adalah rata-rata dari $\varepsilon_{t}^{2}, n$ adalah banyaknya data pengamatan, $p$ adalah orde pada model ARCH. 


\section{KEAKURATAN PERAMALAN}

Kriteria pemilihan model terbaik dalam mengukur keakuratan peramalan salah satunya dengan menggunakan mean squared error (MSE). Semakin kecil nilai MSE maka semakin baik model dalam meramalkan data. Nilai MSE dirumuskan sebagai berikut [9]:

$$
M S E=\frac{\sum_{i=1}^{n}\left(Y_{t}-\hat{Y}_{t}\right)^{2}}{n}
$$

dengan $Y_{t}$ adalah nilai aktual data, $\hat{Y}_{t}$ adalah nilai peramalan data dan $n$ adalah banyaknya data pengamatan.

\section{MODEL GENERALIZED AUTOREGRESSIVE CONDITIONAL HETEROSCEDASTICITY (GARCH)}

Model GARCH merupakan salah satu model runtun waktu yang dapat digunakan untuk menggambarkan sifat dinamik fungsi volatilitas (standar deviasi) dari data. Bentuk umum model GARCH dapat dilihat sebagai berikut [3]:

$$
\hat{\sigma}_{t}^{2}=\omega+\sum_{i=1}^{p} \alpha_{i} \varepsilon_{t-i}^{2}+\sum_{j=1}^{q} \beta_{j} \sigma_{t-j}^{2}
$$

dengan $\omega$ adalah konstanta, $\beta_{j}$ adalah parameter GARCH ke- $j, \alpha_{i}$ adalah parameter ARCH ke- $i, \varepsilon_{t}$ adalah proses white noise, $p$ adalah orde ARCH dan $q$ adalah orde GARCH. Jika $\mathrm{q}=0$ maka model yang terbentuk adalah ARCH. Bentuk koefisien dari model GARCH (p,q) memiliki sifat sebagai berikut:

1. $\omega>0$

2. $\alpha_{i} \geq 0$ untuk $\mathrm{i}=1,2, \ldots \mathrm{p}$

3. $\beta_{j} \geq 0$ untuk $\mathrm{j}=1,2, \ldots \mathrm{q}$

4. $\sum_{i=1}^{p} \sum_{j=1}^{q}\left(\alpha_{i}+\beta_{j}\right)<1$

\section{BACKPROPAGATION}

Backpropagation merupakan salah satu algoritma pelatihan dari jaringan saraf tiruan. Backpropagation melatih jaringan untuk mendapatkan keseimbangan antara kemampuan jaringan untuk mengenali pola yang digunakan selama pelatihan, serta kemampuan jaringan untuk memberikan respon yang benar terhadap pola masukkan (input) yang serupa (tapi tidak sama) dengan pola yang dipakai selama pelatihan [4]. Salah satu metode pembelajaran terawasi pada jaringan saraf tiruan adalah backpropagation. Algoritma backpropagation menggunakan error output untuk mengubah nilai bobot-bobotnya dalam arah mundur. Untuk mendapatkan error tersebut, tahap perambatan maju (feed forward) dikerjakan terlebih dahulu [10].

Arsitektur jaringan yang digunakan backpropagation adalah jaringan layar jamak (multi layer network) yang terdiri atas beberapa lapisan tersembunyi (hidden unit). Semakin banyak jumlah layer dan hidden unit yang digunakan menunjukkan semakin kompleks jaringan yang dibangun, semakin baik hasil peramalan dan semakin lama waktu yang dibutuhkan untuk melakukan pelatihan [11]. Fungsi aktivasi yang dipakai dalam backpropagation yaitu [4]:

1. Fungsi sigmoid biner

Fungsi sigmoid biner yang memiliki range $[0,1]$. Bentuk umum fungsi sigmoid biner dapat dilihat sebagai berikut.

$$
f(x)=\frac{1}{1+e^{-x}} \text { dengan turunan } f^{\prime}(x)=f(x)(1-f(x))
$$

2. Fungsi sigmoid bipolar

Fungsi lain yang sering dipakai adalah fungsi sigmoid bipolar yang bentuk dan fungsinya mirip dengan fungsi sigmoid biner, tapi dengan range $[-1,1]$. Bentuk umum fungsi sigmoid bipolar dapat dilihat sebagai berikut. 


$$
f(x)=\frac{2}{1+e^{-x}}-1 \text { dengan turunan } f^{\prime}(x)=\frac{(1+f(x))(1-f(x))}{2}
$$

Fungsi sigmoid memiliki nilai maksimum $=1$. Maka untuk pola yang targetnya $>1$, pola masukan dan keluaran harus terlebih dahulu ditransformasikan sehingga semua polanya memiliki range yang sama seperti sigmoid yang dipakai.

3. Fungsi identitas

Alternatif lain adalah menggunakan fungsi aktivasi sigmoid hanya pada layar yang bukan layar keluaran. Pada layar keluaran, fungsi aktivasi yang dipakai adalah fungsi identitas $f(x)=x$.

Algoritma pelatihan untuk jaringan dengan satu layar tersembunyi (dengan fungsi aktivasi sigmoid biner) adalah sebagai berikut [4]:

Langkah 0 : Inisialisasi semua bobot dengan bilangan acak kecil.

Langkah 1 : Jika kondisi penghentian belum terpenuhi, lakukan langkah 2-8.

Langkah 2 : Untuk setiap pasang data pelatihan, lakukan langkah 3-8.

Fase I : Feed forward

Langkah 3 : Tiap unit masukan menerima sinyal dan meneruskannya ke unit tersembunyi di atasnya.

Langkah 4 : Hitung semua keluaran di unit tersembunyi $z_{j}(\mathrm{j}=1,2, \ldots, \mathrm{H})$

$$
\begin{gathered}
z_{-} \text {net }_{j}=v_{j o}+\sum_{i=1}^{I} x_{i} v_{j i} \\
z_{j}=f\left(z_{\text {net }_{j}}\right)=\frac{1}{1+e^{-z_{n e t}}}
\end{gathered}
$$

Langkah 5 : Hitung semua keluaran jaringan di unit $y_{k}(\mathrm{k}=1,2, \ldots, \mathrm{g})$

\section{Fase II : Backpropagation}

$$
\begin{gathered}
y_{-} \text {net }_{k}=w_{k o}+\sum_{j=1}^{H} z_{j} w_{k j} \\
y_{k}=f\left(y_{\text {net }_{k}}\right)=\frac{1}{1+e^{-y_{n e t_{k}}}}
\end{gathered}
$$

Langkah 6 : Hitung faktor $\delta$ unit keluaran berdasarkan kesalahan di setiap unit keluaran $y_{k}(\mathrm{k}=1$, $2, \ldots, \mathrm{g})$.

$$
\delta_{k}=\left(t_{k}-y_{k}\right) f^{\prime}\left(y_{n e t_{k}}\right)=\left(t_{k}-y_{k}\right) y_{k}\left(1-y_{k}\right)
$$

$\delta_{k}$ merupakan unit kesalahan yang akan dipakai dalam perubahan bobot layar di bawahnya (langkah 7).

Kemudian hitung suku perubahan bobot $w_{k j}$ (yang akan dipakai nanti untuk merubah bobot $w_{k j}$ ) dengan laju percepatan $\alpha$.

$$
\Delta w_{k j}=\alpha \delta_{k} z_{j} ; \quad \mathrm{k}=1,2, \ldots, \mathrm{g} ; \mathrm{j}=0,1, \ldots, \mathrm{H}
$$

Langkah 7 : Hitung faktor $\delta$ unit tersembunyi berdasarkan kesalahan di setiap unit tersembunyi $z_{j}(\mathrm{j}$ $=1,2, \ldots, \mathrm{H})$.

Faktor $\delta$ unit tersembunyi:

$$
\delta_{n e t_{j}}=\sum_{k=1}^{g} \delta_{k} w_{k j}
$$

$$
\delta_{j}=\delta_{\text {net }_{j}} f^{\prime}\left(z_{n e t_{j}}\right)=\delta_{\text {net }_{j}}=\delta_{\text {net }_{j}} z_{j}\left(1-z_{j}\right)
$$

Kemudian hitung suku perubahan bobot $v_{j i}$ (yang akan dipakai nanti untuk merubah bobot $v_{j i}$ ).

$$
\Delta v_{j i}=\alpha \delta_{j} x_{i} ; \quad \mathrm{j}=1,2, \ldots, \mathrm{H} ; \mathrm{i}=0,1, \ldots, \mathrm{I}
$$

Fase III : Perubahan bobot

Langkah 8 : Hitung semua perubahan bobot

Perubahan bobot garis yang menuju ke unit keluaran:

$$
w_{k j}(\text { baru })=w_{k j}(\operatorname{lama})+\Delta w_{k j}(\mathrm{k}=1,2, \ldots, \mathrm{g} ; \mathrm{j}=0,1, \ldots, \mathrm{H})
$$

Perubahan bobot garis yang menuju ke unit tersembunyi:

$$
v_{i j}(\text { baru })=v_{i j}(\operatorname{lama})+\Delta v_{i j} ;(\mathrm{j}=0,1, \ldots, \mathrm{H} ; \mathrm{i}=0,1, \ldots, \mathrm{I})
$$


Setelah pelatihan selesai dilakukan, jaringan dapat dipakai untuk pengenalan pola. Dalam hal ini, hanya propagasi maju (langkah 4 dan 5) saja yang dipakai untuk menentukan keluaran jaringan. Apabila fungsi aktivasi yang dipakai bukan sigmoid biner, maka langkah 4 dan 5 harus disesuaikan. Demikian juga turunannya pada langkah 6 dan 7.

\section{MODEL NEURO-GARCH}

Model Neuro-GARCH merupakan gabungan antara model GARCH dan JST. Pada model NeuroGARCH, input yang digunakan adalah variabel bebas dari model GARCH yang terbentuk dan targetnya adalah data return (aktual). Bentuk umum persamaan Neuro-GARCH untuk memodelkan data return sebagai berikut [12].

$$
\hat{Y}_{t}=f^{o}\left(\sum_{j=1}^{H} w_{j}^{o} f_{j}^{h}\left(\sum_{i=1}^{I} v_{j, i}^{h} Y_{t-1}+v_{j, i}^{h} \varepsilon_{t-1}+b_{j}^{h}\right)+b^{o}\right)
$$

dengan $\hat{Y}_{t}$ adalah variabel yang diramalkan, $f^{o}$ adalah fungsi aktivasi output, $f_{j}^{h}$ adalah fungsi aktivasi lapisan tersembunyi ke-j, $w_{j}^{o}$ adalah bobot lapisan tersembunyi ke- $j$ ke lapisan output, $v_{j, i}^{h}$ adalah bobot lapisan input ke- $i$ ke lapisan tersembunyi ke- $j, b_{j}^{h}$ adalah bobot bias lapisan tersembunyi ke-j, $b^{o}$ adalah bobot bias lapisan output, $h$ adalah lapisan layar tersembunyi (hidden layer).

Arsitektur multi layer feed forward networks (FNN) dan recurrent neural networks (RNN) lapisan layar tersembunyi tunggal yang mewakili model AR(r) dan ARMA(r,s) disajikan pada Gambar 1 dan Gambar 2 [13].

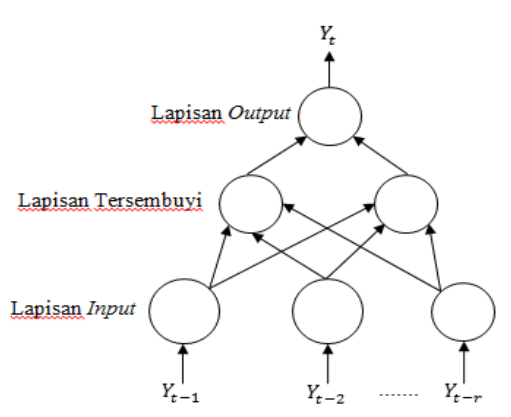

Gambar 1 FNN dengan lapisan tersembunyi tunggal mewakili model $\mathrm{AR}(\mathrm{r})$ nonlinier

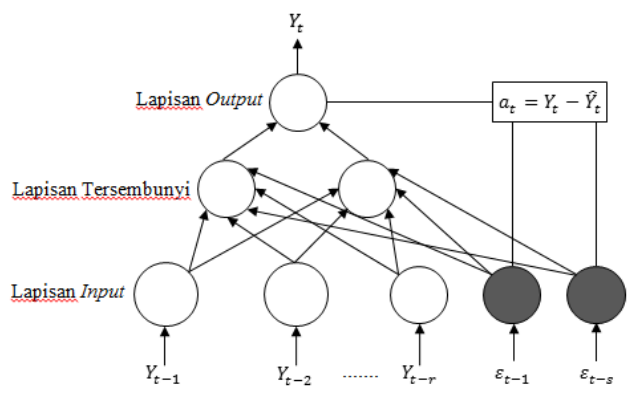

Gambar 2 RNN dengan lapisan tersembunyi tunggal mewakili model

$\operatorname{ARMA}(r, s)$ nonlinier

Sehingga bentuk arsitektur jaringan Neuro-GARCH pada penelitian ini disajikan pada Gambar 3.

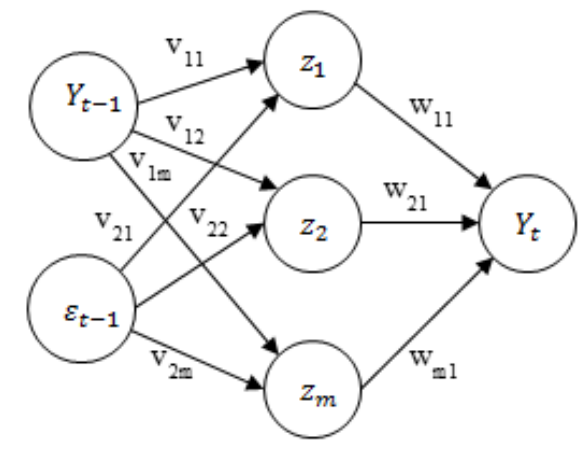

Gambar 3 Arsitektur Jaringan Neuro-GARCH

\section{STUDI KASUS}

Data yang digunakan dalam penelitian ini adalah data return saham PT Bank Central Asia Tbk penutupan harian dari bulan Januari 2017 sampai dengan bulan Februari 2019. Dalam penelitian ini, 
hanya dilakukan peramalan pada return Bank Central Asia tanpa meramalkan volatilitasnya. Dengan menggunakan uji augmented dickey-fuller (ADF), diketahui bahwa data return saham sudah stasioner karena nilai prob $<0,05$. Selanjutnya pendugaan model awal box jenkins dapat ditentukan melalui plot ACF dan PACF. Plot ACF dan PACF return saham dapat dilihat pada Gambar 4.

\begin{tabular}{|c|c|c|c|c|c|c|}
\hline Autocorrelation & Partial Correlation & & $A C$ & PAC & Q-Stat & Prob \\
\hline di & di & 1 & -0.139 & -0.139 & 10.837 & 0.001 \\
\hline 1 & - & 2 & -0.122 & -0.145 & 19.241 & 0.000 \\
\hline 1 & 叫 & 3 & -0.011 & -0.052 & 19.304 & 0.000 \\
\hline 1 & d & 4 & -0.046 & -0.077 & 20.477 & 0.000 \\
\hline קו & 1) & 5 & 0.101 & 0.077 & 26.250 & 0.000 \\
\hline ¿ 1 & ¿l & 6 & -0.096 & -0.089 & 31.493 & 0.000 \\
\hline 1 & 1) & 7 & -0.030 & -0.039 & 31.995 & 0.000 \\
\hline ידן & 111 & 8 & 0.047 & 0.013 & 33.242 & 0.000 \\
\hline 11 & $1 / 1$ & 9 & -0.011 & -0.007 & 33.307 & 0.000 \\
\hline 111 & $1 / 1$ & 10 & 0.009 & -0.004 & 33.355 & 0.000 \\
\hline $1 / 1$ & 111 & 11 & 0.003 & 0.016 & 33.360 & 0.000 \\
\hline $1 \mid 1$ & $1 \mid 1$ & 12 & -0.005 & -0.001 & 33.371 & 0.001 \\
\hline יקו & 111 & 13 & 0.028 & 0.020 & 33.836 & 0.001 \\
\hline יקו & יקו & 14 & 0.038 & 0.055 & 34.648 & 0.002 \\
\hline 1 & $1 \mid 1$ & 15 & -0.026 & -0.003 & 35.023 & 0.002 \\
\hline 10 & 10 & 16 & -0.051 & -0.046 & 36.509 & 0.002 \\
\hline וp & 111 & 17 & 0.032 & 0.023 & 37.110 & 0.003 \\
\hline 11 & 11 & 18 & -0.015 & -0.021 & 37.235 & 0.005 \\
\hline $1 / 1$ & 11 & 19 & -0.004 & -0.011 & 37.245 & 0.007 \\
\hline 10 & 10 & 20 & -0.047 & -0.049 & 38.528 & 0.008 \\
\hline
\end{tabular}

Gambar 4 Plot ACF dan PACF

Berdasarkan Gambar 4 nilai ACF dan PACF yang berada di luar selang kepercayaan $( \pm 1,96 \sqrt{1 / n}$ atau sama dengan $\pm 0,082973$ ) adalah pada lag 1 dan lag 2 . Sehingga model awal box jenkins yang diuji yakni $\operatorname{AR}(1), \operatorname{MA}(1), \operatorname{ARMA}(1,1), \operatorname{ARMA}(1,2), \operatorname{ARMA}(2,1), \operatorname{AR}(2), \operatorname{MA}(2)$ dan $\operatorname{ARMA}(2,2)$. Dalam pemodelan Neuro-GARCH model MA tidak dapat digunakan sebagai input jaringan saraf tiruan (JST) (Gambar 1 dan Gambar 2) [13]. Selanjutnya dilakukan estimasi parameter model-model yang telah diperoleh. Model yang signifikan adalah $\operatorname{AR}(1), \operatorname{ARMA}(1,1)$ dan $\operatorname{AR}(2)$ karena nilai prob < 0,05. Dari ketiga model tersebut yang tidak memiliki korelasi antar lag (white noise) adalah model $\operatorname{ARMA}(1,1)$ dan AR(2). Berdasarkan nilai AIC terkecil diperoleh model terbaik adalah ARMA $(1,1)$, selanjutnya dilakukan uji ARCH-LM. Berdasarkan uji ARCH-LM diperoleh nilai prob. $\mathrm{F}=0,0078<$ 0,05 . Sehingga dapat disimpulkan bahwa terdapat efek heteroskedastisitas pada residual kuadrat model ARMA(1,1), maka dilanjutkan ke model GARCH.

Model awal GARCH yang dibentuk yakni $\operatorname{GARCH}(1,1), \operatorname{GARCH}(1,2), \operatorname{GARCH}(2,1)$ dan $\operatorname{GARCH}(2,2)$. Selanjutnya dilakukan estimasi parameter dan uji sigifikansi. Diperoleh kesimpulan bahwa model yang signifikan adalah $\operatorname{GARCH}(1,1)$ karena nilai prob $<0,05$. Berdasarkan uji ARCHLM pada model GRACH $(1,1)$ diketahui nilai prob. $\mathrm{F}=0,5998>0,05$. Dengan demikian tidak terdapat efek heteroskedastisitas pada residual kuadrat model $\operatorname{GARCH}(1,1)$. Selanjutnya dilakukan pengujian korelasi residual dengan melihat nilai setiap lag pada model $\operatorname{GARCH}(1,1)$. Diperoleh hasil bahwa tidak ada korelasi antar lag karena nilai prob > 0,05. Dari hasil pengujian yang telah dilakukan diperoleh bahwa model GARCH $(1,1)$ sudah memenuhi kelayakan model, sehingga dapat digunakan dalam peramalan return saham PT Bank Central Asia Tbk. Estimasi parameter model $\operatorname{GARCH}(1,1)$ berdasarkan model ARMA $(1,1)$ adalah sebagai berikut.

$$
\begin{gathered}
\hat{Y}_{t}=0,001059+0,497083 Y_{t-1}+\varepsilon_{t}+0,677335 \varepsilon_{t-1} \\
\hat{\sigma}_{t}^{2}=0,0000288+0,075334 \varepsilon_{t-1}^{2}+0,734682 \sigma_{t-1}^{2}
\end{gathered}
$$

Berdasarkan model GARCH(1,1), mean model pada Persamaan (10) digunakan untuk memodelkan data return dan variance model pada Persamaan (11) digunakan untuk memodelkan data volatilitas. Dengan menggunakan Persamaan (10) diperoleh nilai $\hat{Y}_{t}, Y_{t-1}, \varepsilon_{t}$ dan $\varepsilon_{t-1}$ sebanyak 558 data. Data tersebut dibagi menjadi $70 \%$ data pelatihan dan $30 \%$ data pengujian. Sehingga terdapat 391 data pelatihan (dari tanggal 2 Januari 2017 sampai dengan 10 Juli 2018) dan 167 data pengujian (dari 
tanggal 11 Juli 2018 sampai dengan 28 Februari 2019). Nilai $Y_{t-1}$ dan $\varepsilon_{t-1}$ menjadi input dan nilai $Y_{t}$ (return) menjadi target pada model Neuro-GARCH.

\section{Pemodelan Neuro-Garch}

Berdasarkan data hasil peramalan dengan model $\operatorname{GARCH}(1,1)$ dibentuk jaringan dengan 2 unit input dan 1 unit output. Jumlah layar tersembunyi yang digunakan dalam penelitian ini sebanyak 1 lapisan dengan jumlah unit adalah kelipatan 5 yakni, 5, 10 dan 15. Jumlah unit layar tersembunyi pada setiap data dimulai dari jumlah unit terkecil. Sehingga arsitektur jaringan Neuro-GARCH yang terbentuk adalah (2-5-1), (2-10-1) dan (2-15-1). Selanjutnya menggunakan parameter-parameter input dalam pelatihan dan pengujian. Parameter-parameter tersebut disajikan pada Tabel 1.

Tabel 1 Inisialisasi Parameter Model Neuro-GARCH

\begin{tabular}{lc}
\hline \multicolumn{1}{c}{ Parameter } & Nilai Uji \\
\hline Maksimum Epochs (Iterasi) & 5,000 \\
Target error & 0,01 \\
Learning rate $(\alpha)$ & 0,5 \\
Metode pelatihan & Traingdm \\
Fungsi aktivasi & Sigmoid bipolar \\
\hline
\end{tabular}

Proses pelatihan akan berhenti apabila MSE jaringan mendekati atau lebih kecil dari target yang ditentukan atau jumlah epochs (iterasi) mencapai batas maksimal target yang ditentukan. Pemilihan model terbaik didasarkan pada nilai MSE pengujian yang dihasilkan. Semakin kecil nilai MSE maka semakin baik model tersebut. Diperoleh hasil MSE proses pengujian model Neuro-GARCH terkecil adalah (2-5-1) dengan nilai MSE sebesar 0,00014955.

\section{Peramalan Dengan Neuro-Garch}

Hasil peramalan dengan menggunakan model arsitektur jaringan Neuro-GARCH (2-5-1) dalam bentuk grafik perbandingan data aktual dan data peramalan, disajikan pada Gambar 5.

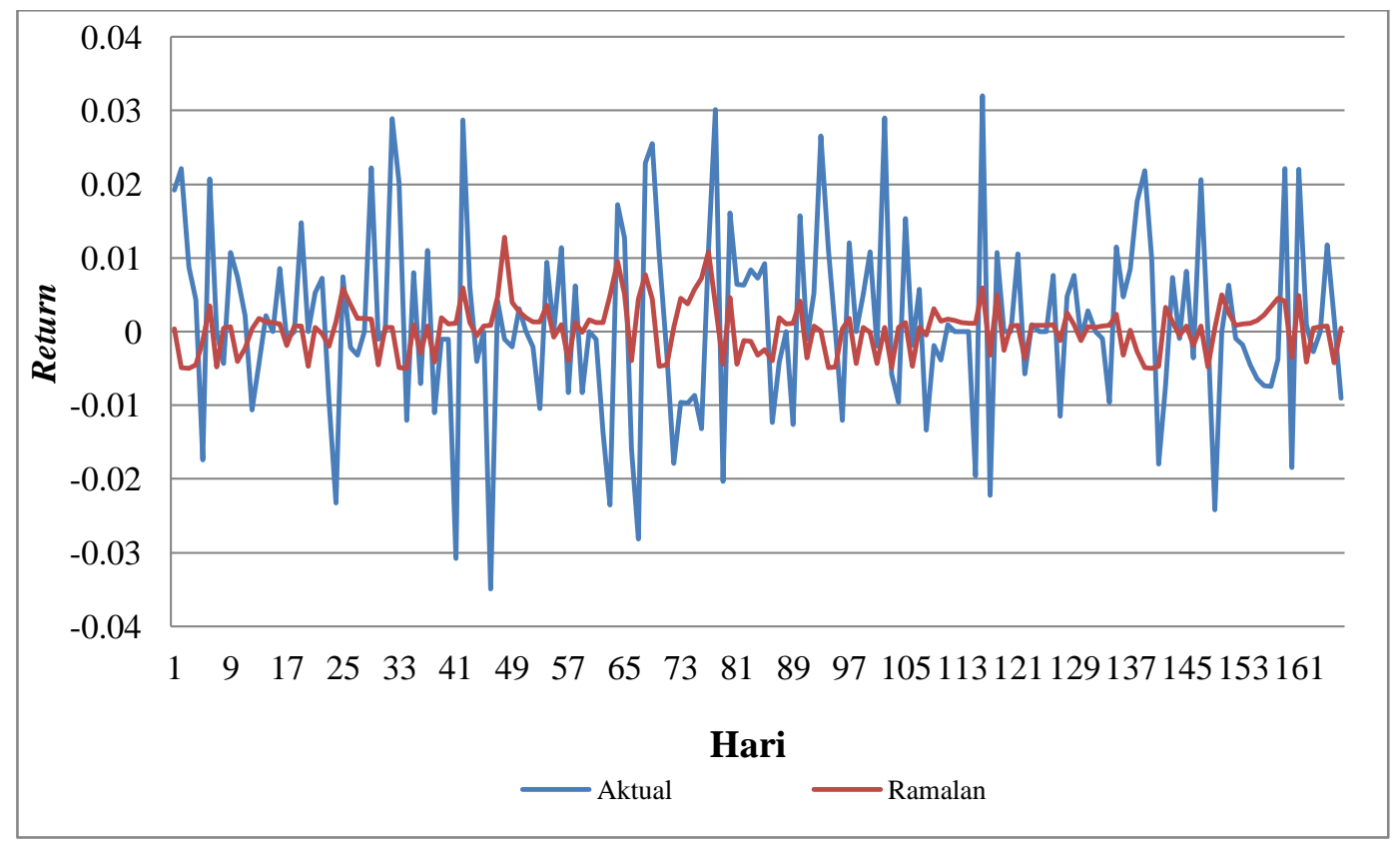

Gambar 5 Grafik Perbandingan Data Aktual Dan Data Peramalan

Dari Gambar 5 diketahui bahwa hasil ramalan selama 167 hari mengalami fluktuasi. Data hasil peramalan return saham PT Bank Central Asia Tbk tertinggi yaitu pada tanggal 14 September 2018 sebesar 0,0128467 dan terendah terjadi pada tanggal 13 Juli 2018 sebesar -0,0049574. 


\section{KESIMPULAN}

Berdasarkan hasil penelitian yang dilakukan maka diperoleh kesimpulan sebagai berikut:

1. Bentuk arsitektur jaringan model terbaik Neuro-GARCH dalam meramalkan return saham PT Bank Central Asia Tbk adalah model jaringan unit lapisan (2-5-1) dengan nilai MSE pengujian sebesar 0,00014955.

2. Data hasil peramalan return saham PT Bank Central Asia Tbk selama 167 hari mengalami fluktuasi, return tertinggi yaitu pada tanggal 14 September 2018 sebesar 0,0128467 dan terendah terjadi pada tanggal 13 Juli 2018 sebesar -0,0049574.

\section{DAFTAR PUSTAKA}

[1]. Noeryanti. Aplikasi Pemulusan Eksponensial dari Brown dan dari Holt untuk Data yang Memuat Trend. Prosiding Seminar Nasional Aplikasi Sains \& Teknologi (Snast) Periode III, Jurusan Matematika Fakultas Sains Terapan Institut Sains \& Teknologi AKPRIND Yogyakarta; 2012.

[2]. Sulisyanto. Ekonometrika Terapan : Teori \& Aplikasi dengan SPSS. Yogyakarta: Andi Offset; 2011.

[3]. Rosadi, D. Ekonometrika \& Analisis Runtun Waktu Terapan dengan Eviews. Yogyakarta: Andi Offset; 2012.

[4]. Siang, J.J. Jaringan Syaraf Tiruan dan Pemogramannya Menggunakan Matlab, Yogyakarta: Andi; 2005.

[5]. Chen, W.Y. dan Lian, K.K. A Comparison of Forecasting Models for Asean Equity Markets. Sunway Academic Journal. 2005; 2(4):1-12.

[6]. Azzam, I. The Effect of Model-Selection Uncertainty on Autoregressive Models Estimates. International Research Journal of Finance and Economics. 2007; 2(11):80-93.

[7]. Enders, W. Applied Econometric Time Series. United States of America: John Wiley \& Sons, Inc; 2015.

[8]. Tsay, R.S. Analysis of Financial Time Series. United States of America: John Wiley \& Sons, Inc; 2005.

[9]. Makridakis, S., Wheelwright, C.S. dan McGee, V.E. Metode dan Aplikasi Peramalan, Jilid 1 Edisi 2 [Andriyanto, U,S, dan Basith, A, (alih bahasa)]. Jakarta: Erlangga; 1992.

[10]. Kusumadewi S. dan Hartanti, S. Neuro-Fuzzy : Integrasi Sistem Fuzzy \& Jaringan Syaraf Edisi Kedua. Yogyakarta: Graha Ilmu; 2010.

[11]. Hansun, S. Peramalan Data IHSG Menggunakan Metode Backpropagation. Ultimatics. 2013; 4(1):26-30.

[12]. Ramadhani, T.R. Penerapan Model Neuro-GARCH untuk Peramalan Data Saham (Studi Kasus pada Saham Bank Central Asia Tbk, Saham Bayan Resources Tbk, dan Saham Lippo Cikarang Tbk). Jurnal Mahasiswa Statistik. 2013; 1(1):1-4.

[13]. Arnerić, J. GARCH Based Artificial Neural Networks in Forecasting Conditional Variance of Stock Returns. Croatian Operational Research Review. 2014; 5(2):329-343.

NOVA ANDARESTA $\quad$ : Jurusan Matematika FMIPA UNTAN, Pontianak nova.andaresta@student.untan.ac.id

SHANTIKA MARTHA $\quad$ : Jurusan Matematika FMIPA UNTAN, Pontianak shantika.martha@math.untan.ac.id

DWI MARISA MIDYANTI : Jurusan Sistem Komputer FMIPA UNTAN, Pontianak dwi.marisa@siskom.untan.ac.id 